\title{
DET SLESVIGHOLSTENSKE KANCELLI OG RESKRIPTET AF 15. DECEMBER 1810
}

(OM DANSK SPROGS INDFØRELSE I SØNDERJYLLAND)

AF

KNUD FABRICIUS

DR. PHIL., PROFESSOR VED UNIVERSITETET, KøBENHAVN

*

T ong Frederik VI.s Reskript til det slesvig-holstenske Kancelli af den 1 I5. Decbr. I810 om det danske Sprogs Indførelse ved Gudstjenesten, Skoleundervisningen og Rettergangen overalt i Hertugdømmet Slesvig, hvor det var „Almeenmands Sprog“ “, har faaet en sørgelig Berømmelse i vor Historie. Forordningens Skæbne er bekendt. Den blev sammen med de indkomne Beretninger om de sproglige Forhold i de enkelte Amter og Stæder "henlagt" af det slesvig-holstenske Kancelli, og Efterverdenen er ikke bleven træt af at forbavses og forarges over dette Udslag af bureaukratisk Egenmægtighed. Ja, man har generaliseret her ud fra til en Dom over hele Enevælden mellem I66o og 1848: Saa svag var den enevældige Konge, at han ikke en Gang kunde tvinge sine egne Embedsmænd til Lydighed, men at disse ved passiv Modstand kunde neutralisere snart sagt alle hans Paabud!

I denne skarpe Form fremtraadte Dommen over Reskriptets Behandling ikke i Samtiden. Denne kendte det forøvrigt ikke direkte, men kun fra den Skikkelse, hvori det gengaves i Kancelliets Skrivelse til den gottorpske Overret d. I9. Jan. det følgende Aar. Heri paabødes det Retten at oplyse om de lokale Forhold og at afgive Betænkning om, hvorledes Kongens Vilje bedst lod sig udføre ${ }^{2}$. I denne Skrivelse var der forøvrigt i Stedet for Ordene „hvor det er Almeenmands Sprog “ brugt det langt vagere Udtryk: „Hvor der tales Dansk.“ Denne Kancelliskrivelse blev almindelig kendt, og det er om denne og dens Skæbne, der altid tales i de følgende 40 Aar. Her er det da værdt at lægge Mærke til, at medens en Mand

1 Ifølge Ordbog over det danske Sprog I, 465 betyder „Almenmand“ „Menigmand, Almuesmand". ${ }^{2}$ Som H. Hjelholt har oplyst, blev Reskriptet selv forst almindelig bekendt i I 85I (Den danske Sprogordning og det danske Sprogstyre i Slesvig mellem Krigene, S. 223 f.). 
som Werlauff i sit Prisskrift af I8I 9 nævner Skrivelsen uden Kommentar, er det først Chr. Paulsen, der i 1832 i sit berømte Skrift „Uber Volksthümlichkeit und Staatsrecht" ${ }^{1}$, Fanen for hele den slesvigske Sprog- og Nationalitetskamp, rejser den første, svage Kritik mod de tyske Øvrigheder. Meget forsigtigt hedder det heri: „Man har maaske - hvis der tør ytres en Formodning - ikke vist sig helt imødekommende over for Hs. Maj. Kongens velvillige Planer", og Paulsen motiverer dette, dels med Embedsstandens ringe Kendskab til Dansk, dels med en vis Modstand i den offentlige Mening. Som man ser, er disse Ord endda ikke særligt møntede paa Kancelliet ${ }^{2}$. Endnu da Allen I848 i „Antislesvigholstenske Fragmenter" udgav det første Udkast til sit store Sprogværk under Titlen „Om Sprog og Folke-Eiendommelighed i Hertugdømmet Slesvig eller Sønderjylland", gik han heri ikke videre end til at bebrejde den danske Regering „Svaghed og Vaklen“ i Sprogsagen i 8 I I. Det var aabenbart først Forbindelsen med Regenburg, som bragte Allen til at anslaa kraftigere Toner og vende Angrebet mod selve Kancelliet. Var det et gammelt Modsætningsforhold mellem de to Kancellier; - Regensburg tilhørte som bekendt det danske; - som fik ham til altid at nære Mistanke til det slesvig-holstenske Kancellis Redelighed? I I85 I mistænkte han det saaledes for med Vilje at have tilintetgjort Reskriptet af 18 Io, en Mistanke, der ikke vel kunde opretholdes, da det straks efter fandtes indført i Kancelliets Kopibog ${ }^{3}$. Senere var det sikkert ham, der havde saa stor Indflydelse paa Allen og forsynede denne med det meste af Stoffet til „Det danske Sprogs Historie i Hertugdømmet Slesvig eller Sønderjylland“ (1857), som ogsaa indplantede ham det Syn paa Kancelliets Behandling af Sprogsagen, der gaar igennem dette Værk: Kollegiet har vel, „som man maa antage“, drøftet Sagen, efter at have modtaget Indberetningerne fra de slesvigske Lokalmyndigheder. Men det har aldrig refereret Sagen for Kongen, thi i Journalen er der ved Siden af dens Indførelse skrevet: „Wegzulegen“. Og derefter gemte det Aktstykkerne saa godt, at de aldrig siden blev fundne. „Det slog ikke blot Sagen ihjel, men det begrov ogsaa hemmeligt den Dræbte".

„Altsaa“", - opsummerer Allen Sagens Forløb,— „Kongen befaler sit Kancelli: Undersøg denne Sag, indhent Beretninger, som kunne tjene til at oplyse den, drøft den derpaa vel og fremlæg for mig en Plan, hvorledes den efter Eders Skjøn hurtigst og bedst kan fremmes; saa er min Villie. Beretninger indkomme fra alle Slesvigs Amter, Provstier, Kjøbstæder og Sogne, og Betænkninger fra

1 Samlede mindre Skrifter II, 403. 2 I en senere Artikel fra I 839 søger Paulsen Grunden til Planens Stranding — „ausser einzelnen Missgriffen“ — i de politiske Begivenheder 1813-I8I4 (stds. 440). ${ }^{3}$ H. Hjelholt, S. $223 \mathrm{f}$. 
alle Autoriteter. Kancelliet modtager dem, overveier dem, og betænker, hvad Følger disse Beretninger og Betænkninger maatte have, naar Kongen blev bekjendt med deres Indhold; og da det slesvig-holstenske Kancelli vel har overveiet alt dette, saa beslutter det, at det Hele skal blive en skjult Ting for dets Herre og Konge - det beslutter om Sagen og alle dens Akter sit tørre Wegzulegen. Frederik den Sjette blev aldrig bekjendt med den".

Allens Ord kom ganske vist ikke til at staa uimodsagte, ja, Modsigelsen fremkom endda adskillige Aar, før „Det danske Sprogs Historie“ saa Lyset. A. S. Ørsted vendte sig 1852 i sin "Af mit Livs og min Tids Historie“ mod den Opfattelse af det slesvigholstenske Kancellis Optræden i i 81 o, som allerede da var gængs, og udtaler: „Vel har jeg været aldeles udenfor den Deel af Bestyrelsen, hvorom her er Tale“; - han sad jo i Danske Kancelli; - „men de Personer og de Forhold, som derved kunne komme i Betragtning, vare mig saa nøie bekjendte, at jeg ei alene har den fuldkomneste Overbeviisning om, at hiin Mistanke er aldeles ugrundet, men endog seer mig istand til at understøtte denne min Overbeviisning med saa indlysende Grunde, at jeg tør gjøre Regning paa ogsaa at fremkalde lige Overbeviisning hos andre". Han pegede $i$ denne Hensigt paa, at Reskripterne ikke udtrykte en Befaling fra Kongen, men kun et Formaal hos denne, og han paaberaabte sig den Garanti for Kancelliets Holdning, som laa i, at baade Møsting og Rothe havde Sæde deri. Kancelliet havde aldeles ikke været modstræbende, ,skjøndt en eller anden Enkelt kan have været i Tvivl om Omfanget og Maaden"1.

Ørsteds Argumentation virkede aldrig helt overbevisende i Danmark; - en anden Sag var det naturligvis i tyske Kredse ${ }^{2}$; - lige til vore Dage er der vedblevet at klæbe en Mistanke ved Kancelliets Holdning, som vore Historikere har udtrykt mere eller mindre skarpt efter deres stærkere eller svagere Interesse for hele det paagældende Spørgsmaal. I I892 udtalte M. Rubin, at „som bekendt viste det slesvig-holstenske Kancelli ikke samme Iver for at standse Slesvigs Fortyskning“ [som Kongen] ${ }^{3}$, og Edv. Holm pegede i „Danmarks Riges Historie" som Forklaringsgrund for den mærkelige Stansning ikke blot paa de følgende Aars politiske Ulykker, men ogsaa paa „den Ulyst, de forskellige tyske Autoriteter ... viste med Hensyn til Gennemførelsen af Kongens Ønsker" 4 . Lidenskabsfuldt kommer den Allenske Stemning til Orde saa

1 A. S. Ørsted: Af mit Livs og mine Tids Hist. II, 307 f. (1852). - Paa S. 240-24I synes Ø. endnu ikke at kende Reskriptet af 1810 ; i hvert Fald var dette ikke Tilfældet, da han 1850 skrev „For den danske Stats Opretholdelse“. 2 Se Aug. Sach: Das Herzogthum Schleswig III, 413. ${ }^{3}$ 1807-14, S. 4 II. ${ }^{4} \mathrm{~V}, 688$. 
sent som igi I hos $H$. Rosendal, naar han udbryder: „Kancelliet ... havde besluttet at trodse eller bedrage Kongen"1, mens Axel Linvald mere behersket forklarer Henlæggelsen med „Misfornøjelse med Kongens Hensigter eller Frygt for de praktiske Vanskeligheder"2. I afsvækket Form er altsaa Allens og Regenburgs Synspunkt vedblevet at leve, og det maa indrømmes, at det ogsaa kunde søge en vis Bekræftelse i de ovenfor citerede Slutningsord hos Ørsted.

Men iøvrigt maa man undre sig over, at den Tanke, som Ørsted havde fremsat, ikke blev taget op, at se paa de Mænd, som den Gang sad i det slesvigholstenske Kancelli, og spørge, om man kan tiltro dem en saadan Handlemaade. Præsident for Kancelliet var indtil 1813 den senere Finansminister Møsting, der i dette Aar afløstes af Otto Moltke. Begge hørte til Kongens mest trofaste Tjenere; Moltke havde ligesom Møsting i 1806 været en Tilhænger af de saakaldte Daniseringsplaner over for Holsten. Er Frederik VI bleven ført bag Lyset af Kancelliet, maa det samme gælde om dettes Præsidenter. Af egentlige Kancelliraader fandtes der $\mathrm{i}$ denne Tid kun seks. Af disse døde $\mathrm{Kr}$. Janssen allerede 13. Marts I8I I, saa at han ikke kan komme i Betragtning i denne Forbindelse; noget lignende maa gælde om v. Eggers, der I $_{\text {I }} 3$ blev Overpræsident i Kiel. Han var forøvrigt mangeaarig dansk Embedsmand, nøje knyttet til A. P. Bernstorff, i hvis Skole man ikke lærte at spille Statens Overhoved paa Næsen. Fra Hammerich kan vi sikkert ogsaa fjerne al Mistanke; han blev siddende i Kancelliet lige til 1833 , og vilde altsaa være kommen til at bøde for sin mulige Ulydighed i I 829, da Kongens Opmærksomhed efter Allens Mening atter blev vakt for Spørgsmaalet. Tilbage staar tre Kancelliraader, F. K. Jensen, Dahlmanns Morbroder og Medudgiver af Ridderskabets Privilegier, som først fratraadte r820; Andreas Bjørn Rothe (1809-33) og Spies, som I821 blev Kansler ved Overretten paa Gottorp. Paa en af disse tre skulde vel Ansvaret falde, og man har virkelig ogsaa søgt at hæfte det ved Spies paa Grund af hans senere slesvig-holstenske Sympatier ${ }^{3}$. Men ved Spies' Side sad altsaa samtidig i Kancelliet Rothe, der ikke blot er bleven kaldt „en Type paa den oplyste Enevældes brave og fuldtro Mænd“, men som heller ikke ved andre Lejligheder veg tilbage for at indtage et kærnedansk Standpunkt, selv naar det bragte ham i Modsætningsforhold til Flertallet af Kollegiets Medlemmer. Skulde han have lukket Øjnene for, at hans Kollega „syltede“ Sagen? Og som Chef for Kancelliets første Sekretariatskontor virkede $1_{8} I_{1}-13$ den senere saa berømte Professor Niels Falck,

1 Trak af Danskhedens Hist. i Sønderjylland I, 9I. ${ }^{2}$ Det danske Folks Hist. VI, 218. ${ }^{3}$ H. R. Hiort-Lorenzen i Dansk Biogr. Lex. XVI, 223. 
der endnu i 1838 i Stænderforsamlingen var en varm Ven af det danske Sprogs Beskyttelse i hans egen Hjemegn Nordslesvig.

Intet taler derfor for, at Kancelliet skulde være gaaet uden om Sagen. Grunden til, at den blev opgivet, maa ligge andet Steds. Men ganske vist; ingen har hidtil kunnet følge Sagen længere end til det Øjeblik, da den efter at have gaaet sin Kredsgang i Sønderjylland fra Myndighed til Myndighed vendte tilbage til København og bankede paa Kancelliets Dør. Selv de i Hertugdømmet indhentede Betænkninger og Forslag kendes ikke længer fra Originalerne, men kun fra de i Overrettens Arkiv bevarede Kopier. Kom det overhovedet til Forhandlinger i Kancelliet om Spørgsmaalet, og hvilken Holdning indtog de ovenfor nævnte Herrer herunder? Vi har intet andet hidtil vidst derom end Ordet „Wegzulegen“. Det maa derfor vist kaldes et interessant Fund, som Forfatteren af denne Afhandling gjorde, da han for faa Aar siden af Kancellipræsidentens Papirer i Rigsarkivet fremdrog et meget omfattende Aktstykke (I5 firesidige Folioark), der ved nærmere Undersøgelse viste sig at være Koncepten til Spies' Indlæg under Kollegiets Drøftelse om Udførelsen af Reskriptet af i5. Decbr. I81o. Endnu værdifuldere blev dette Dokument ved at vise sig ogsaa at gengive Hovedtrækkene af to andre Kollegiemedlemmers, Møstings og Rothes, Standpunkter, der refereres af Spies, efterhaanden som han i sit Votum finder Anledning til at polemisere mod dem. Det er herefter muligt i de store Træk at rekonstruere Kancelliets Behandling af Sagen, selv om det ikke bør overses, at vi kun kender Præsidentens og Rothes Standpunkter gennem Spies' Fremstilling. Taler end alt for, at de er gengivne korrekt ${ }^{1}$, er det dog sandsynligt, at disse to Indlæg har indeholdt adskilligt værdifuldt, som Spies ikke har fundet sig foranlediget til at imødegaa, og som derfor for bestandig vil blive skjult for os, hvis da ikke et nyt lykkeligt Fund skulde give os ogsaa disse to Dokumenter i Hænde.

Frederik VI.s Interesse var tidligt bleven vakt for det sønderjyske Problem; hans Kammerjunker og fortrolige Johan Bülow har Eren for allerede I 784 at have henledt hans Opmærksomhed paa Betydningen af, at „det danske Sprog straks blev indført i Sønderjylland og lidt efter lidt i Holsten "2. De sidste Ord viser allerede Forskellen mellem Nutidens folkelig-nationale og Datidens statslignationale Synsmaade. Forbilledet var formodentlig den Gang Kejser Josef II

I Spies' Indlæg blev jo ogsaa bekendt for de to andre Medlemmer. Det vil blive trykt in extenso i Danske Magasin 1932. ${ }^{2}$ Hist. Tidsskr. 7. R. VI, 9. 
af Østrig, der søgte at indføre Tysk som Regeringssprog $i$ alle sine Stater for derved at svejtse dem fastere sammen. For Kronprins Frederik blev disse Tanker imidlertid først til Virkelighed, da han I8o6 oplevede det tysk-romerske Kejserriges Sammenbrud, der stillede ham over for Spørgsmaalet om Holstens nærmere Tilknytning til den dansk-norske Helstat. Den kraftige Centralisation i fransk Sprog og Aand, som Napoleon da havde gennemført inden for sit Rige i Overensstemmelse med Revolutionens Tanker, maatte nu være det lysende Forbillede. Meget mindre Betydning for Kronprinsen har sikkert den nye aandelige Bevægelse, Romantiken, haft, der paa denne Tid var i Færd med at afløse Rationalismen i alle germanske Lande, og som lagde Hovedvægten paa alt folkeligt, deriblandt ogsaa Sproget. Frederik VI forstod aldrig meget heraf, saaledes som det fremgaar af hans Holdning til vor Guldalderdigtning og dens sceniske Ydelser. Han var helt og holdent det I8de Aarhundredes Mand, ligesom Josef II og Napoleon; for ham var den centraliserede Stat Hovedsagen, selv om han forud for sine store samtidige havde den Egenskab at besidde en vis folkelig Sans.

Til at dvæle ved hans mislykkede Forsøg i i 806 paa en Indlemmelse af Holsten, er der her ingen Anledning. Derimod maa der mindes om hans Reskripter fra de følgende Aar om, at alle Forordninger for Hertugdømmerne skulde udfærdiges baade paa Dansk og Tysk (3. Dec. I807); at alle Bestallinger sammesteds skulde affattes paa Dansk (2. Dec. I8og); at alle Embedskandidater skulde anføre i deres Ansøgninger, om de besad det fulde Herredømme over det danske Sprog (23. Okt. I8I I); at theologiske Kandidater fra Københavns Universitet skulde være fuldt berettigede til Ansættelse i Hertugdømmerne (5. Novbr. I 8 I I); at der skulde oprettes en Lærestol ved Kiels Universitet i dansk Sprog og Literatur (5. Jan. I8I I). Endelig gjordes det 7. Sept. I812 til Pligt for alle, der ansøgte om Embeder, at godtgøre, at de beherskede det danske Sprog, og dette Krav udstraktes 5. Juni 1813 til ogsaa at gælde for Advokater. Ind i denne Række kongelige Paabud træder ogsaa det betydningsfuldeste, det tidligere nævnte Reskript af 15 . Decbr. I8 Io om dansk Sprogs Indførelse i Sønderjylland som Kirke-, Skole- og Retssprog overalt, hvor det „er Almeenmands Sprog“.

Efterat Kancelliet i Jan. det følgende Aar havde paalagt Overretten paa Gottorp at fremskaffe Betænkninger i Anledning af Reskriptet fra de lokale Myndigheder, indløb disse i de følgende Maaneder indtil April Maaneds Slutning, hvorpaa Generalsuperintendent Adler udtalte sig, og Overretten og Overkonsistoriet 20. August oversendte samtlige Dokumenter tilligemed sin egen Betænkning til Kancelliet. Der er saa meget mindre Grund til at komme nær- 
mere ind paa denne lange Række Udtalelser, som Allen i sit bekendte Værk har ofret ikke mindre end 40 Sider $^{1}$ paa at referere deres Indhold. Dog maa der $\mathrm{i}$ to Henseender føjes nogle Ord til Allen. Den første gælder hans Omtale af de optrædende Personer. Naar Allen erklærer, at „, i det Hele taget er den tydskdannede Embedsstand ogsaa tydsksindet, indtagen imod det Sprog, som Kongen vilde beskytte“, er der - historisk set - nok saa megen Grund til at pege paa det modsatte, at de enkelte retfærdige, som fandtes i Israel, var udgaaede fra Københavns Universitet, hvad der gør deres Holdning mindre overraskende. Dette gælder saaledes om Provst Prahl i Tønder, der som født Bornholmer var Kandidat fra København. Dernæst kan det bemærkes, at de tyskdannede Embedsmænd, som var uvilligt stemte mod Reformen, ogsaa fra dansk Side roses som iøvrigt dygtige og ansete Mænd. Det gælder saaledes om Provsterne Strodtmann i Haderslev, Jacobsen i Flensborg og Boysen i Gottorp Amt, som derfor maa antages at have talt ud fra deres bedste Overbevisning. Heri ligger ingenlunde nogen Billigelse af deres Standpunkt i Sprogsagen. Hvad Amtmændene angaar, - der iøvrigt paa de fleste Steder træder tilbage bag de mere kyndige Provster og følger disses Indstilling, - bør man lægge Mærke til, at naar de stiller sig køligt over for Kongens Ønske, drejer det sig i Reglen om ældre eller svagelige Mænd, der derfor maa forudsættes at have været i Besiddelse af ringe Initiativ. Bertouch i Tønder var saaledes 66 Aar, Jørgen Ahlefeldt i Slesvig 63 og desuden svagelig; Feldmann i Flensborg erklærer selv i sit Svar, at Lægens Forbud „und die Schwäche meiner Augen und Denkkraft" hindrer ham i at gaa nærmere ind paa Sagen; Kai Werner Ahlefeldt i Haderslev var ganske vist endnu en yngre Mand, men bekendt for sit indesluttede og hypokondre Væsen ${ }^{2}$. Man kan godt forstaa, om saadanne Mænd af personlige Hensyn har gyst tilbage for de med Forandringen forbundne Besværligheder. Omvendt har det sin Interesse at bemærke, at Amtmand Stemann i Aabenraa, der er meget ivrig for at udføre Kongens Tanke, kun er 37 Aar gammel, foruden at vel den Omstændighed, at han var Broder til den senere Statsminister Poul Christian Stemann, kan formodes at have givet ham en mere dansk Indstilling end de øvrige ${ }^{3}$. Hvad endelig hans jevnaldrende, Amtmanden i Sønderborg Linstow, angaar, er der allerede tidligere bleven protesteret mod Allens Opfattelse af ham som en Modstander af Kongens Reskript og peget paa, at han iøvrigt altid „lagde et udpræget dansk Sindelag for Dagen“4. En fordomsfri

1 II, S. 44-86. ${ }^{2}$ Om alle de hidtil nævnte henvises til Dansk Biogr. Lexikon, for K. W. Ahlefeldts Vedkommende desuden til L. Bobé: Slægten Ahlefeldts Hist. III, I $8 .{ }^{3}$ Om ham se Zeitschrift f. s.-h.-1. Geschichte XL. ${ }^{4}$ G. Kringelbach i Dansk Biogr. Lex. X, 335. 
Prøvelse af Linstows Indlæg vil da ogsaa vise, at han ikke mindre end Amtmanden i Aabenraa sluttede sig til Kongens Plan, men at han i højere Grad havde $\varnothing_{j e t}$ aabent for Vanskelighederne ved at gennemføre den, nemlig Embedsmændenes mangelfulde Herredømme over det danske Sprog. Han anbefalede derfor først og fremmest at have Opmærksomheden rettet paa Embedsvakancer og sørge for, at de nyudnævnte Embedsmænd var „det danske Sprog fuldkommen mægtige“, for at man derefter kunde skride til „Indførelsen af det danske Sprog som Forretningssprog i de herværende Amter“.

Viser det sig saaledes, at personlige Forhold har haft deres Betydning ved Embedsmændenes Skøn om Reformens Nytte og Gennemførlighed, er der paa den anden Side Grund til at pege paa - hvad Allen har udeladt i sin Gengivelse af Aktstykkerne -, at ogsaa Tilhængere af Reformen, som Stemann og Linstow, var klar over den praktiske Nytte, som Kendskabet til Tysk kunde have for Befolkningen i deres nordslesvigske Amter. Stemann gjorde opmærksom paa, at mange Bønder i Aabenraa og Løgumkloster Amter forstod noget Tysk, navnlig de, der drev Heste- og Kvæghandel og derfor besøgte Markederne. I Staden Aabenraa maatte Tysk bevares i Kantorens Skole, da den besøgtes af dem, der vilde gaa den studerende Vej, og denne Vej førte til Kiel. For de øvriges Vedkommende, som vilde slaa ind paa det praktiske Livs Baner, burde der paa Forlangende i deres Skoler gives Undervisning i Tysk. Om Sønderborg siger Linstow: „Helt, forekommer det mig, vilde man ikke kunne afskaffe det tyske Sprog og tysk Præken i Sønderborg, for ikke at udelukke de mange tyske Haandværkere, der sædvanlig samler sig i Byerne, fra Deltagelse i den offentlige Gudstjeneste og berøve dem al Lejlighed til Opbyggelse. Desuden findes der i Sønderborg Embedsmænd og andre Honoratiores, hvem det tyske Sprog er "geläufiger" end det danske, og som derfor hellere vil høre en tysk Præken"1. Forholdene var altsaa ikke saa lige til, som man skulde tro efter Allens Fremstilling.

Hovedresultatet af Underinstansernes Førstebehandling af Sagen er bekendt. Medens Amtmand og Provst i Haderslev er enige om at fraraade Forandringen, er de i Aabenraa lige saa enige om det modsatte; i Sønderborg stiller Amtmanden sig, om end med Forsigtighed, paa det samme Stade. Paa alle disse Steder fandtes der dog i Forvejen dansk Kirkesprog og Skolesprog paa Landet, saa at det kun var om Retssproget samt om Stæderne, Reformen drejede sig. Noget anderledes laa Forholdene i Tønder Amt, hvis nordlige Halvdel fulgte Indretningen i Nordslesvig med Hensyn til Kirke- og Skolesprog, mens disse i

1 De to Amtmænds Indlæg er her benyttede efter Koncepterne i deres Arkiver (Staatsarchiv Kiel: C II, I Nr. I I og C III, I Nr. 150). 
den sydlige Del, Kærherred, var tyske. I Tønder var, som nævnt, Provst Prahl for dansk Kirke- og Skolesprogs Indførelse i Kær Herred, mens Amtmanden var imod dansk Retssprog i alle Amtets Dele. Endelig var i Flensborg og Gottorp Amter Amtmændene og Provsterne enige om at stille sig imod enhver Forandring; - en anden Holdning indtog dog en Del angelske Godsejere, og navnlig den bekendte Justitiarius Jaspersen paa Runtofte; - mens omvendt i Husum Amt Amtmanden var villig til at gaa med til Dansks Indførelse, ikke blot i de dansktalende, men ogsaa i de frisiske Sogne. Ja, selv Magistraten i Husum By stillede sig velvillig over for en gradevis Indførelse af det danske Sprog.

Fra Underinstanserne gik Sagen sin regelmæssige Gang til Melleminstanserne: Overkonsistoriet og Overretten paa Gottorp Slot. I den første af disse mente Generalsuperintendent Adler efter nogen Vaklen, at man burde indskrænke sig til at indføre Dansk som Kirke- og Skolesprog i Udbjerg Sogn og største Delen af Kærherred, mulig med Tilføjelse af Bov og et Par andre Sogne i Vis Herred, ligesom han kunde gaa med til en Udvidelse af Dansk som Kirkesprog i de fleste nordslesvigske Købstæder. Hertil sluttede Provst Boysen fra Slesvig sig, og dette blev Overkonsistoriets almindelige Standpunkt. Hvad Retssproget og Bestyrelsessproget angaar, udtalte Overretten sig ifølge Allen for, at der heri ikke burde gøres nogen Forandring „paa een Gang eller i Løbet af faa Aar, men kun gradevis". Allen har imidlertid udeladt Slutningen af Overrettens Betænkning, der viser, at den hermed ingenlunde ønskede Sagen udskudt ,ad calendas Graecas". „Hvad endelig de Forholdsregler angaar", skriver Retten, „der maa tages, for at Indførelsen og den videre Udbredelse af det danske Sprog kan forberedes og iværksættes gradevis i den kortest mulige Tid, vil vi i saa Henseende henvise til de almindelige Forslag, som Provst Boysen har føjet til Slutningen af sin Betænkning, og som synes os meget formaalstjenlige ${ }^{1}$. Imidlertid maa vi anbefale som Midler, der allerede $n u$ kunde anvendes til at opnaa det tilsigtede Maal, at man ved Besættelsen af ledige Embeder, af hvad Art de end er, tog særligt Hensyn til Kendskab til dansk saa vel som tysk Sprog, og at de yngre Præster, Skolelærere, Embedsmænd og Advokater opfordredes og opmuntredes til at lære Dansk, naar Tid og Lejlighed dertil foreligger" 2 .

Hermed var Sagen indanket til den øverste Embeds-Myndighed, Kancelliets, Kendelse. Som man ser, var der ikke fra nogen Side - naar undtages spredte Stemmer i Angel og Amtmanden i Husum - taget til Orde for dansk Kirke-

1 De gik ud paa Ansættelsen af en Professor i Dansk ved Kiels Universitet, og at theologiske og juridiske Kandidater $\mathrm{i}$ begge Hertugdømmer ved deres Eksamen skulde underkastes en Prøve i Dansk. (Allen II, 82). '2 Rigsark. SHL Kanc. „Dän. Sprache 181 I-49“ I. 
og Skolesprogs Indførelse syd for Kær Herred og de nordlige Sogne af Vis Herred. Skulde Kancelliet komme til et for det danske Sprog gunstigere Resultat, maatte det enten bygge paa et yderligere Kendskab til de lokale Forhold, end det sad inde med gennem Embedsmændenes Betænkninger, eller paa almindelige Betragtninger. Kancelliets Resultat vil fremgaa af SpIEs' nyfundne Betænkning.

Det var formodentlig i Efteraaret 18 I , at Sagen kom for i Kancelliet, men da Spies' Indlæg er udateret, er det ikke muligt at bestemme Tidspunktet nøjere ${ }^{1}$. Det maa formodes, at man har begyndt med en mundtlig Drøftelse af Sagen, og at Uoverensstemmelserne allerede herunder har vist sig saa store, at man har foretrukket at udarbejde de forskellige Standpunkter skriftligt. Af disse forelaa Præsident Møstings og Rothes Indlæg, før Spies førte sit i Pennen. Om ogsaa de øvrige Assessorer, v. Eggers, Hammerich og Jensen, har udtalt sig skriftligt eller ej, kan ikke siges. Rimeligst er det vel, at dette ikke er sket; i modsat Fald vil man nærmest tro, at de har sluttet sig til Spies' Opfattelse.

Holsteneren Joachim Otto Friedrich Spies havde 18ro i en Alder af kun 3o Aar opnaaet at blive Assessor i Kollegiet. Allerede dette vidner om hans fremragende administrative Evner, der iøvrigt er almindeligt anerkendte og skaffede ham høj Gunst hos Kongen, ikke mindst fordi de var forbundne med et udpræget enevældigt Sindelag. Dette Indtryk bestyrkes af det foreliggende Aktstykke. Hvilken Dom man end vil fælde over Spies' Standpunkt i den slesvigske Sprogsag, kan der kun være een Mening om den Maade, hvorpaa han førte sin Sag; juridisk Skarpsindighed mangler hans Indlæg saa vist ikke.

Spies begynder med at pege paa en Uoverensstemmelse i Reskriptet af 15. Decbr. I8 ro mellem Præmisser og Konklusion, nemlig, at der først tales om de Distrikter, hvor Dansk er Folkesproget, og senere om, at Kancelliet skal fremkomme med en Forestilling til Kongen om Indførelsen hurtigst muligt, men dog gradevis „af det danske Sprogs Brug i alle offentlige Anliggender i Vort Hertugdømme Slesvigs forskellige Amter, Distrikter og underliggende Øer", hvilket kunde opfattes som: i hele Slesvig. Men denne Uoverensstemmelse er efter hans Mening kun en tilsyneladende, thi der maa gaa den samme Tankegang gennem hele Reskriptet, og Slutningen kan derfor kun tale om de slesvigske Distrikter, hvor de tidligere nævnte sproglige Betingelser foreligger. Dette fremgaar jo ogsaa af Kancelliets Skrivelse til Overretten af i9. Jan., som kun om-

1 Da der i Spies' Indlæg aabenbart sigtes til Kongens Forordninger af 23. Okt. og 5. Novbr. I8I I, kan det ikke være affattet for nogen Tid efter disses Fremkomst. 
handler de Distrikter, „hvor der tales Dansk“. Meningen er klar: Det er ikke Kongens Hensigt at udvide det danske Folkesprogs Grænser, men kun at indføre Dansk som offentligt Sprog i de Egne, hvor Dansk er Folkesprog. Derfor skal Kancelliet kun afgive Beretning om Folkesprogets Stilling, men derimod Forslag til det offentlige Sprogs ÆEndring.

Man maa baade fra juridisk og historisk Synspunkt give Spies Ret i denne Opfattelse, men man mærker tillige, at hans Bemærkning har polemisk Karakter. Den er aabenbart rettet mod Kancellipræsident Møsting og imod Andreas Bjørn Rothe. Man indser ikke let, hvorledes disse to Medlemmer af Kancelliet, hvis deres Opfattelse af Kongens Mening var rigtig, i Begyndelsen af samme Aar havde kunnet gaa med til at skrive til Overretten: „Da det er Hans Kongelige Majestæts Vilje, at i de til Hertugdømmet Slesvig hørende Distrikter, Amter og Øer, hvor der tales Dansk, det danske Sprog lidt efter lidt skal indføres ved Gudstjenesten" o.s.v. Bordet fangede. De to Mænd kunde ikke et halvt Aar senere hævde en anden Opfattelse af Kongens Vilje, og det Materiale fra de lokale Myndigheder, paa Grundlag af hvilket man nu skulde gøre sin Indstilling til Kongen, var ubestridelig tilvejebragt ud fra andre Forudsætninger.

Spies havde saaledes paa dette Punkt let Spil over for sine to Modstandere. Han behøvede ikke en Gang at polemisere direkte mod dem m. H. t. Opfattelsen af Reskriptet, men indskrænkede sig til at spørge, „om Kancelliet af Grunde, som laa $i$ Sagen selv, havde Anledning til at udstrække sin Forestilling til videre gaaende Forholdsregler end dem, hvorpaa Kongens Hensigt ifølge Reskriptet var rettet“. Kancellipræsident Møsting har herpaa svaret Ja og ytret, „at en gradvis Indførelse af det danske Sprog i begge Hertugdømmer var at anbefale“. Rothe har derimod indskrænket sig til, ,at.Dansk skulde gøres til det herskende Sprog i hele Hertugdømmet Slesvig “. Rothe har dog ment, at Kancelliet ogsaa burde udtale sig om Holsten, „da de efter Reskriptet af 15. Decbr. I81o udstedte allerhøjeste Forordninger synes at antyde det som Kongens Hensigt, ogsaa at indføre det danske Sprog i Holsten “.

Her faar vi altsaa de to andre Medlemmers Standpunkt, men desværre kun i Spies' Referat. Hvad mener Møsting og Rothe med Ordene „dansk Sprog“? Tænkte Møsting sig t. Eks. foruden dansk Regeringssprog at indføre dansk Præken i Holsten? Vilde han gaa saa vidt som til at fortrænge det tyske Folkesprog fra dette Land? Vi véd det ikke. Saa meget er kun sikkert, at Spies i sin Replik drog de yderste Konsekvenser af sin Modstanders maaske kun uklare Tanker og fremstillede dem som rettede mod tysk Kultur og Sprog. Ud herfra havde han saa meget lettere ved ogsaa at faa Ram paa Rothe. 
Spies erklærede sig uenig med sine Kollegaer i deres Opfattelse af Kongens sidste Forordninger, hvormed der aabenbart var sigtet til Reskripterne af 23. Oktbr. og 5. Nvbr. om Embedsmændenes Kendskab til Dansk. De afgav altsaa intet Vidnesbyrd om, at Kongen skulde ønske Tysk fortrængt, hvor det var Folkesprog. Og i hvert Fald burde man da i Forvejen have hørt de lokale Embedsmænd, ganske særligt den slesvigske og den holstenske Overret, naar det drejede sig om en saa vigtig Sag som en Forandring af Folkesproget. Men dette var jo slet ikke sket. Derfor kunde man heller ikke gaa ind paa hele dette Spørgsmaal i Indstillingen til Kongen.

Man burde derfor holde sig til Reskriptet af 1810. Men Spies besluttede sig til, før han gik nærmere ind paa dette, at slaa et positivt Slag for Folkesprogets Eksistensberettigelse, saa meget mere, som han herved kunde støtte sig paa Rothes Opfattelse, naar det drejede sig om Holsten. Spies' Udtalelser er paa dette Punkt saa mindeværdige, at de fortjener at gengives i deres fulde Omfang: „Et Folks hele Dannelse sammenhænger paa det inderligste med Sproget. Sproget er det Middel, hvorved al Kultur skabes, d. v. s. Udviklingen af Menneskets aandelige Indhold. Selv de højeste Ideer, de religiøse saa vel som de sædelige, opfattes og tilegnes kun af Folket $\mathrm{i}$ dets oprindelige Sprog. Disse Ideer nedarves fra Generation til Generation og griber ind i Nationens Liv. Naar man paatvinger Folket et fremmed Sprog, bliver deres stadige Vækst afbrudt, den helligste Arv fra Forfædrene gaar tabt for Efterkommerne. Det fremmede, som ikke tilhører dem, bliver ikke grebet med samme Kraft af dem som det ejendommelige (eller: som hvad der er deres Ejendom) (das eigenthümliche). Naar disse højeste Ideer forelægges dem i fremmed Sprogdragt, taber de i Klarhed og Inderlighed; deres velsignelsesrige Indvirkning paa Handling og Liv bliver svækket.

Paa samme Maade forholder det sig med den intellektuelle Udvikling [„Verstandesbildung"], der kun finder Sted gennem Sproget og skrider fremad i Forbindelse med dette. Ogsaa denne bliver afbrudt, naar det nye Sprog indføres, og først naar det fremmede Sprog hos Folket er blevet til Modersmaal, falder den Hindring for Forstandsudviklingen, som var indtraadt, atter bort. Imidlertid vil der gaa Aarhundreder, før Folket — der jo dog kun kan have eet Sprog til sit egentlige Sprog - glemmer dette og lærer det nye i den Grad, at det besidder det som sin Ejendom. De mellemliggende Generationer bliver Aarhundreder igennem hindrede $i$ deres aandelige Udvikling.

Over for saadanne Hensyn maa alle andre vige, og de her fremstillede Følger af et fremmed Sprogs Paatvingen kan ikke opvejes ved de Fordele, som man 
maaske vilde haabe at naa ved en fjern politisk Enhed gennem Overensstemmelse i Folkesproget. " -

Der er om denne Udvikling af Spies kun at sige, at den er saa sand, som den er sagt. Hans Opfattelse falder saa nøje i Traad med Fichtes i „Reden an die deutsche Nation", der var holdte i Berlin et Par Aar tidligere, at Slægtskabet er umiskendeligt. Nutiden vil ganske knæsætte en saadan Betragtning. Kun vil den være tilbøjelig til at mene, at hvad der i I8I I gælder for det tyske, ogsaa $i$ senere Tider maa have Gyldighed for andre Folkesprog.

Spies støtter sig yderligere paa Rothes Indvending mod at indføre dansk Sprog i Holsten, nemlig at dette ikke er nødvendigt for at opnaa den tilstræbte Statsenhed, men at det tværtimod vil modvirke denne, der bygger paa „enig Tilslutning til det fælles Statsbaand“, altsaa paa et Følelsesmoment. De historiske Eksempler, som Rothe anfører paa mislykkede Denationaliseringsforsøg, stammer endda fra Forsøg af Erobrerkonger, mens det jo i dette Tilfælde drejer sig om en lovmæssig Hersker. Det eneste Eksempel paa det modsatte er Josef II's Forsøg over for Ungarn, der som bekendt strandede fuldstændigt. Ydermere kan det tilføjes, at det $\mathrm{i}$ saadanne Tilfælde altid har drejet sig om at indføre et højere udviklet eller videre udbredt Sprog, som Romerne i de erobrede barbariske Lande, eller Grev Gert med det tyske Sprog i Jylland og Kejser Napoleon med Fransk i Rhindepartementerne. I de to sidste Tilfæelde maa man $\mathrm{i}$ hvert Fald indrømme, at Sejrherrens Sprog var mere udbredt eller da lige saa udbredt som de besejredes. Men naar Talen er om Tysk og Dansk, vil vel ingen kunne paastaa, at det tyske Sprog er mindre fuldkomment end det danske, og dertil kommer, at det tales af I9 Gange saa mange Mennesker som dette.

Spies maa derfor fraraade en Forandring af Folkesproget gennem Regeringsforordninger baade nu og i Fremtiden. Selv om en saadan Forholdsregel kun gennemføres gradevis, er og bliver den skadelig. Saa meget om Forholdet for Holstens Vedkommende.

Han vender sig derefter til Slesvig.

Med Hensyn til Folkesprog maa man her skelne mellem tre Dele: De dansktalende og de tysktalende Distrikter samt endelig "saadanne Distrikter, hvor det daglige Sprog hos Folket hverken er Tysk eller Dansk, men en af begge disse Sprog samt af det engelske og det franske(!) sammenblandet Dialekt, eller ogsaa Frisisk“.

Hvor Dansk er „Almuemands Sprog“, bør det efterhaanden indføres i de offentlige Anliggender, „selv dér, hvor det Danske, som tales af Folket, saaledes som det muligt er Tilfældet i Tønder Amts Geestherreder, er meget provinsielt, 
men iøvrigt ikke afviger mere fra godt Dansk, end at det sidste forstaas af Folket". Paa saadanne Steder er det ubetinget raadeligt, at der indføres dansk Kirkesprog, dansk Retssprog m. m. „At noget andet hidtil er sket, er en øjensynlig Ulempe, hvis Bortrydning ganske vist er forbundet med Vanskeligheder. Men disse er ikke uovervindelige, og de maa vige for Overbevisningen om det overvejende rigtige i Forholdsreglerne."

Omvendt forholder det sig med det Bælte, „hvor tysk Sprog er Folkesprog og har været det i Aarhundreder". Her er Forholdene ganske analoge med Holsten, og alle de almindelige Grunde, som er anførte mod Forandring af et Folkesprog, finder deres fulde Anvendelse her. „Beboeren af Hütten Amt, Landskabet Ejdersted og Øen Femern, Borgeren i Ekernførde, Slesvig og Frederiksstad forstaar lige saa lidt Dansk som Landmanden i Ditmarsken eller Steinbeck og Borgeren i Kiel eller Rendsborg“".

Ganske vist har man ${ }^{1}$ som Grund for at indføre Dansk i hele Hertugdømmet Slesvig beraabt sig paa, at denne Provins altid har hørt til Danmark, at den er beboet af danske, ikke tyske Stammer, og at det danske Sprog i ældre Tid har været det herskende her. Men disse historiske Grunde rører ikke Spies. Over for den første Omstændighed beraaber han sig paa Rothes Indrømmelse af, at politisk Enhed ikke bygger paa Fællessprog, men paa Fællesfølelse, og de to sidste Beviser finder han "meget tvivlsomme“. Det har ikke megen Interesse for Nutiden at gaa ind paa Spies' historiske Argumentation, da den opererer med gamle og kendte, men for længe siden aflivede Travere. Det maa dog indrømmes, at de stod i højere Kurs for hundrede Aar siden baade i Tyskland og i Danmark. Vi faar saaledes at høre, at Sachsere, Frisere og - Nederlændere (Nordstrand og Frederiksstad!) er Tyskere, og Angler „snarest“ det samme. „Derfor“ er det ogsaa højst usandsynligt, at Dansk nogensinde har været det herskende Sprog i Slesvig. At „Jyske Lov “ er affattet paa Dansk, er efter Forfatterens Mening intet Bevis herfor, da den galdt for et større Omraade end Sønderjylland. Ikke hundrede Aar efter "Jyske Lovs“ Udstedelse er jo Aabenraa Stadsskraa affattet paa Tysk o.s. v., o. s. v.

Men, slutter Spies, hvordan det nu end forholder sig med Fortidens Folkesprog, er det en Kendsgerning, at Tysk nu er Folkesprog i en Del af Slesvig. Selv om man indførte Dansk som offentligt Sprog her, vilde Tysk dog vedblive at være Folkesprog i Aarhundreder. Et Bevis herpaa har man i, at i Aabenraa Amt og til Dels i Tønder Amt tales der endnu Dansk, skønt disse Amter allerede 1490 tilfaldt den gottorpske Hertug ${ }^{2}$ og ved de senere Delinger blev hos

1 Altsaa Møsting og Rothe. ${ }^{2}$ Dette gælder som bekendt ikke om Aabenraa Amt. 
ham, der indførte Tysk som offentligt Sprog ${ }^{1}$ og "sikkert" stræbte efter ogsaa at gøre det til Folkesprog. „Hvilket tillige afgiver et Bevis paa, at det nuværende Forhold mellem Sprogene i Slesvig ikke alene er en Følge af politiske Forholdsregler", tilføjer Spies lidt spydigt. Men Hovedsagen er, at hvis man indfører Dansk som offentligt Sprog i det tyske Bælte i Slesvig, faar man her ganske de samme Ulemper, som Reskriptet af 18 Io vil afhjælpe for de dansktalende Egnes Vedkommende.

Tilbage staar det tredje, det mellemliggende Bælte, hvormed Spies altsaa mener Landet fra Kær Herreds Sydgrænse til Danevirke. Her forekommer Spørgsmaalet ham „tvivlsommere“, fordi der efter hans Mening tales den ovenfor nævnte mærkelige Blandingsdialekt. „Denne Dialekt kan man egentlig ikke kalde for et Folkesprog, da den overalt kun tales i det daglige Liv, men ikke bruges som Skriftsprog." Heri støtter Spies sig paa Indberetningerne fra Provsterne Boysen i Slesvig og Jacobsen i Flensborg, af hvilke den sidste betegnes som „,en født Angler, der kender det tyske og det danske Sprog“. Disse Embedsmænd er endda enige om, at Dialekten staar Tysk nærmere end Dansk. Indbyggerne forstaar ikke "godt Dansk“ [Rigssprog], hvilket viser sig, naar Feltpræster i Angel har forsøgt at holde Prækener for en betydelig Tilhørerkreds. Hvad Frisisk angaar, som Spies henregner til det samme Bælte, anser han det for at staa Dansk endnu fjernere. Men Tysk har i de frisisktalende Distrikter i mange Aar været brugt som offentligt Sprog og som Skriftsprog; Indbyggerne forstaar derfor alle Tysk, „der i denne Henseende ( $\mathrm{:} \mathrm{i} \mathrm{Kirken} \mathrm{og} \mathrm{for} \mathrm{Retten)}$ og som Skriftsprog egentlig er Folkesprog paa dette Sted "2.

Her er vi ved det springende Punkt i hele Spies' Betænkning, Forslaget om, hvorledes man skal gaa frem $i$ det Bælte, som han - i en anden Betydning end senere Regenburg - betegner som „blandet“, og hvortil han altsaa ogsaa regner det frisisktalende Omraade. Paa Grund af det betydningsfulde er der ogsaa her Anledning til at gengive Forslaget ordret, idet det maa forudskikkes, at Spies paa Grundlag af Embedsmændenes Beretninger fremstiller det, som om det her kun er de ældre Folk, som indbyrdes taler dette „Blandingssprog “ eller Frisisk, mens de overfor deres Børn og yngre paarørende betjener sig af Tysk. At dette er en ganske fejlagtig Opfattelse af Forholdene i Angel og Midterlandet ved r810, behøver ikke at paavises over for danske Læsere. Spies' Forslag lyder saaledes:

1 Dette galder som bekendt ikke om Kirkesproget, hvilket er af afgørende Betydning i denne Forbindelse. 2 Denne Opfattelse af Begrebet „Folkesprog“ kan næppe siges at stemme synderligt godt med den tidligere af Spies givne, da han talte om det tyske Sprog i Holsten (se ovenfor S. 38-39). 
„Vilde man nu her indføre det danske Sprog ved offentlige Anliggender, vilde Indbyggerne lige saa lidt forstaa dette som paa de Steder, hvor der kun tales Tysk. Man maatte altsaa ogsaa i de Distrikter, hvor den blandede Dialekt hersker, forst gore Dansk til Folkesprog, hvorved i Grunden alle de ovenfor anforte Ulemper vilde indtræde, og desuden Sprogene i disse Distrikter blive brugt ved hinandens Side, nemlig den hidtidige Dialekt $i$ det daglige Liv, Tysk som det Skrift- og Bogsprog, de Voksne har lært, og hvori den opvoksende Ungdom undervises, og Dansk som skal gøres til offentligt Sprog ved de nuværende Foranstaltninger. Følgen vilde blive, at disse Sprog blev indbyrdes blandede, men intet af dem forstaaet saa godt, som det ellers kunde være Tilfældet, og der vilde opstaa en Slags Sprogforvirring. Hvor skadeligt dette virker i mange Henseender, hvor meget det navnlig forhaler og vanskeliggør Undervisningen og Ungdommens Dannelse, synes mig at være indlysende.

Derimod vil, hvis man ikke ved Sprogforordninger afbryder den allerede indtraadte, naturlige Udvikling, Ungdommens Dannelse og de voksnes Forædling, henholdsvis gennem Undervisning og gennem Præken paa et Sprog, som de allerede nu forstaar og ikke først møjsommeligt skal lære, faa sin naturlige Fremgang; i det mindste vil denne ikke blive hæmmet ved selvvoldte Hindringer. Navnlig vil den i disse Distrikter brugelige Dialekt mere og mere forsvinde, og det tyske Sprog, der i Egenskab af Skrift- og Bogsprog allerede nu er Folkesprog, ogsaa blive Dagliglivets Sprog. Men den Omstændighed, at Folket bruger og forstaar et Kultursprog (eine gebildete Sprache), er af Betydning for Statens højere Formaal. Om dette i det ene eller andet Distrikt er Dansk eller Tysk, turde ikke være Hovedsagen. Da nu i de Distrikter, hvor den blandede ufuldkomne Dialekt hersker, et af de to Kultursprog; - hvilket af dem, afhænger af lokale Forhold, Handelsforbindelse m. m., maaske ogsaa af Landets tidligere politiske Forhold; - allerede har gjort saadanne Fremskridt, at man med Sandsynlighed tør slutte, snart at ville se det som eneste Folkesprog, vilde Foranstaltninger, som indførte det andet, for Folket endnu ukendte Kultursprog dér, stride mod hint for Staten vigtige Formaal, uden at der ved de Tilbageskridt, som Folket gennem mange Aar maatte lide, paa anden Vis naaedes nogen væsentlig Vinding " 1 . Spies maa derfor fuldtud slutte sig til de lokale Myndigheders - med Undtagelse af Amtmanden i Husum - Modstand mod, at Reskriptet af i5. Decbr. I8Io udstrækkes til at omfatte det nævnte Distrikt. -

1 I en Sidebemærkning gør Spies opmærksom paa de betydelige Omkostninger, som Indførelsen af Dansk paa et større Omraade vilde medføre, uden dog at tillægge dette Hensyn nogen afgørende Betydning. 
Bortset fra „Tønder Amts Geestherreder“, d.v. s. Kærherred, ønsker Spies altsaa ingen sproglig Forandring gennemført syd for den nuværende Grænse. Han tror ikke blot paa Provsterne Boysens og Jacobsens Teori om „ein SprachGemisch" i Mellemslesvig, men han, der i 6 Aar har tjent i Kancelliet og derfor maa formodes at kende noget til Bestyrelsesforholdene, nævner ikke med eet Ord den Omstændighed, at tysk Kirkesprog, tysk Skolesprog, tysk Retssprog og tysk Bestyrelsessprog $\mathrm{i}$ umindelige Tider har virket her og kan formodes at have bidraget væsentligt til at frembringe, om end ikke den paastaaede Sprogblanding, saa dog et lidet udviklet og stagnerende dansk Folkesprog. Det tør vistnok siges, at man skal lede efter en Fremstilling, der i den Grad sætter Forholdene paa Hovedet. Spørgsmaalet kan kun blive, om Manden herunder virkelig har handlet i god Tro.

Men ser man paa den anden Afdeling af Spies' Betænkning, der omhandler, hvorledes Dansk skal indføres som offentligt Sprog i de Dele af Hertugdømmet, hvor det efter hans Mening er Folkesprog, kan det ikke nægtes, at den bærer et Præg af Oprigtighed, der ogsaa synes at maatte overføres paa det forud sagte. Spies begynder med at gentage, at „det formaalstjenlige i denne Forholdsregel er i høj Grad indlysende“". Det kommer kun an paa Udførelsesmaaden og Overvindelsen af de Vanskeligheder, som Embedsmændene frembyder. Kongen har selv taget til Orde for en gradevis gennemført Reform.

Hvad Kirke- og Skolesproget angaar, er dette allerede dansk i den største Del af det Omraade, hvormed Spies regner. For den øvrige Dels Vedkommende slutter han sig i det væsentlige til Kancellipræsidentens [tabte] Forslag. Hvor Præster og Skolelærere er tilstrækkeligt kyndige i Dansk, bør dette Sprog straks indføres i Kirken og Skolen, dog maaske saaledes, at man i de første 5 Aar bevarer en tysk Præken hver 3 dje eller 4 de Søndag. Hvor de ikke opfylder disse Betingelser fuldtud, bør de opfordres til at lære det, saaledes at der for Skolelærernes Vedkommende stilles Præmier derfor i Udsigt.

De i Dansk kyndige Præster bør selv undervise deres Skolelærere, og de fornødne danske Lærebøger bør anskaffes til Lærerne paa offentlig Bekostning. De Præster, som slet ikke kan Dansk, maa ved passende Lejlighed forflyttes til andre Distrikter. Hvor kun Præsten, men ikke Skolelæreren kan Dansk, skal Gudstjenesten alligevel (med den nævnte Undtagelse) foregaa paa dette Sprog, da Børnene lige som de voksne for største Delen forstaar det. Men i det modsatte Tilfælde skal Religionsundervisningen i Skolen foreløbig ske paa Tysk, af Hensyn til den paafølgende Konfirmationsforberedelse hos den tysktalende Præst. 
Vakante Præste- og Skolelærerembeder bør kun besættes med Mænd, „der er det danske Sprog fuldkomment mægtige“. Dette kan træde i Kraft efter et Aars Forløb, da der ingen Mangel paa Kandidater findes ${ }^{1}$. Men i Byerne bliver det formodentlig nødvendigt at bevare en tysk Præken hver anden eller tredje Søndag af Hensyn til de mange derværende Indbyggere, hvis Sprog er Tysk.

Spies mente iøvrigt, at alle Bøger til Undervisningen og Gudstjenesten burde anskaffes paa den kongelige Kasses Bekostning. Han var ogsaa enig med Møsting $i$, at der ved Visitatserne burde anstilles Undersøgelser og gøres Indberetninger til Kancelliet om, hvorledes Gennemførelsen skred fremad. De Præster og Lærere, som viste sig aktive for at fremme Reformen, burde lønnes med Befordring. Derimod skulde man ikke ved Trudsel om Straf tvinge de nuværende Skolelærere til at lære Dansk, eller tvangsforflytte Præster, som ikke inden en vis Frist havde tilegnet sig Sproget. Navnlig maatte man vente, at det vilde volde Skolelærerne betydelige Vanskeligheder at lære Dansk i den Grad, at de kunde holde ligefremme Foredrag herpaa, men ogsaa for Præsterne var det ingen let Sag at leve sig i den Grad ind i et fremmed Sprog, saa at deres Prækener kunde gribe Tilhørernes Aand og Hjerte. Her var derfor ikke Haardhed, men Overbærenhed paa sin Plads.

Hvad Indførelsen af Dansk som Rets- og Bestyrelsessprog angaar, skal kun Hovedpunkterne i Spies' Forslag her berøres. Uden for $\mathbb{E}$ rø og enkelte Punkter paa Fastlandet var jo Tysk alene Retssprog. Spies saa ikke nogen afgørende Hindring for dettes Afskaffelse i den Omstændighed, at Lovene og Statuterne var affattede paa Tysk. I hele Tyskland havde jo hidtil Romerretten gældt, uden at man derfor havde Latin til Forretningssprog. Hovedsagen var, at Embedsmænd og Advokater lærte Dansk, hvilket maatte ske, før Retssproget ændredes. Nogen bestemt Frist for Embedsmændene turde Spies dog ikke foreslaa, heller ikke vilde han skride til Tvangsforflyttelser, men ligesom ved Præster og Skolelærere mente han, at Vejen maatte være Opfordring og frivillig Forflyttelse. I Lokalstyrelsen holdt han paa, at Sprogforandringen burde indføres herreds-, amts- og købstadsvis, naar de fornødne Betingelser fandtes hos de styrende Autoriteter. Derimod kunde man efter nogle Aars Forløb stille bestemte Krav om fornødent Kendskab til Dansk af de Advokater, som søgte Praksis ved Underretterne, og det samme galdt om Notarerne; de allerede eksisterende Advokater vilde saa nok af egen Interesse lægge sig efter Dansk.

Ved den slesvigske Overret, mente Spies, at der ikke vilde frembyde sig af-

1 Dette viser, at Spies har skrevet sit Votum forud for den kgl. Forordning af 7. Sept. 1812, som fremsatte Kravet herom. 
gørende Vanskeligheder for at behandle de fra dansktalende Distrikter indløbende Retssager paa Dansk; de fleste Medlemmer af Retten havde allerede nu den fornødne Kyndighed i dette Sprog, og ved fremtidige Udnævnelser maatte man stille bestemte Krav om, at en saadan Kyndighed kunde godtgøres. Endelig maatte naturligvis Kollegierne udfærdige deres Resolutioner paa Dansk til de samme Distrikter, saa snart Sprogforandringen her var traadt ud i Livet.

Spies erklærer selv, at han i sine Forslag om at gøre Kundskab i Dansk til en absolut Betingelse ved Embedsbesættelser bygger paa Møsting og Rothe, saa at vi altsaa paa dette Punkt ikke staar over for hans egne Tanker. Prøverne i Sprogfærdighed burde for Skolelærernes Vedkommende aflægges hos Generalsuperintendenten eller den paagældende Provst, hvis han som Prahl i Tønder besad de fornødne Betingelser herfor. Theologiske Kandidater kunde derimod prøves i Dansk i Forbindelse med deres almindelige Eksamen. Med Hensyn til Juristerne anbefaler Forfatteren navnlig at lade Professorerne Jens Baggesen og Claussen deltage i den juridiske Eksamen for den sproglige Sides Vedkommende.

Spies ender sin Betænkning med at udtale, at skønt han altsaa ikke troer at kunne tilraade at gøre det danske Sprog til „Folkesprog“ paa de Steder, hvor det ikke er Folkets Maal, mener han paa den anden Side, at Kendskab til Dansk ved Siden af Tysk bør fremmes paa alle Maader i begge Hertugdømmerne. Derfor bør der træffes Foranstaltninger til, at man kan lære Dansk i Skolerne ${ }^{1}$, paa Seminarierne og ved Kiels Universitet, og man maa ogsaa sørge for, at Studenterne og Seminaristerne virkelig benytter disse Foranstaltninger. I saa Henseende kan han nøjes med at henvise til Kancellipræsidentens Votum, der her er udtømmende, men han kan ikke slutte sig til dennes Bemærkning, at der ogsaa i Skolerne paa Landet og de lavere Klasser af Borgerskolerne bør undervises i Dansk i de Distrikter, hvor Dansk ikke er Folkesprog, thi dette forhindres ved den indskrænkede Undervisningstid. „De lavere Klasser af Folket behøver overalt kun at kende eet Sprog. Man maa søge at bringe dem saa vidt heri, som Omstændighederne tillader det. Ved at blive undervist $i$ et andet Sprog, som de dog kun lærer meget lidt af, bliver de adspredte og forvirrede. De nødvendige Læregenstande og navnlig „Modersmaalet“ vil lide derunder, uden at der ad denne Vej vindes noget væsentligt for en formaalstjenlig Udbredelse af det andet Sprog."

1 Hermed menes, som det fremgaar af nedenstaaende, Latinskolerne og Borgerskolernes højere Klasser. 
Spies' lange Indlæg har den Værdi for os, at det ikke blot sætter os i Stand til at lære hans eget Standpunkt i Sprogsagen at kende, men at det ogsaa giver os nogle Træk af hans to Modstanderes Opfattelser. Desværre altfor faa. Vi ser, hvad der blev ført i Marken mod det danske Talesprog i Mellemslesvig, men vi hører intet om, hvad der blev anført til dets Forsvar. Formodentlig har det ikke været synderlig meget, ikke en Gang i A. B. Rothes Betænkning, thi i saa Fald havde Spies næppe kunnet fremsætte sine uhørlige Paastande om, at Folkemaalet her var et Blandingssprog, og at det ikke kunde betegnes som et Folkesprog, fordi det ikke var noget Skriftsprog. Hvorledes kunde Holstensk klare sig over for en saadan Kritiker, da det jo heller ikke ejede noget Skriftsprog? Rothe synes at have indskrænket sig til historiske Betragtninger, som den at det danske Sprog tidligere havde haft en videre Udbredelse i Slesvig end nu. Men med den Slags Stof lod der sig lettere jonglere af hans Modstander, og som vi har set (S. 4o), lod Spies ikke Lejligheden gaa ubenyttet hen.

Iøvrigt maa det billigvis indrømmes, at Spies i sin Opfattelse af et Sprogs Betydning indtager et mere moderne Standpunkt end sine Kollegaer, $i$ hvert Fald end Møsting (S. 38-39). Det er allerede paapeget, at han her var i Samklang med Fichte; modsat møder vi i den Møstingske Opfattelse noget, der fører Tanken hen paa Fichtes Modstander, Preusseren Adam Müller, der i disse Aar havde sluttet sig nøje til Metternichs System. For Müller var Sproget først og fremmest et Statsanliggende, et vigtigt Middel til at frembringe den snævert afgrænsede Nationalstat. Han talte om en "preussisk“ lige som om en „østrigsk" Nation, mens Fichte ikke vilde afbryde Forbindelsen mellem sin tyske Nationalstat og Menneskeheden, ja for ham i det hele Kosmopolitisme og Patriotisme var et og samme Begreb'. Men naar Nutiden vil række Fichte Palmen, bør den ikke glemme, at det Igde Aarhundredes Statsmænd længe efter Møstings Dage var mere tilbøjelige til at følge den Opfattelse, som Adam Müller havde formuleret i Ord.

Det vil nu være temmelig klart, hvorfor der ikke fulgte noget positivt Resultat af Kancelliets Overvejelser om, i hvilket Omfang og paa hvilken Maade Reskriptet af i5. Decbr. I8ro skulde føres ud i Livet. Det er ganske vist sandsynligt, at de Ulykker, som kort efter stormede ind over den dansk-norske Helstat i Form af økonomisk Ruin og Landafstaaelser, har bidraget deres til at vende Kong Frederik VI.s Opmærksomhed i andre Retninger. Det er ogsaa troligt, at den Uvilje, der var traadt tydeligt frem hos mange af de lokale Embedsmænd, har paavirket ham i samme Retning. Men Hovedsagen maatte

1 Fr. Meinecke: Weltbürgertum und Nationalstaat?, S. I15 ff., $152 \mathrm{ff}$. 
være, at det ikke havde vist sig muligt at samle de ledende Mænd inden for det slesvigholstenske Kancelli om et fælles Synspunkt over for Reformen, saa at der ikke kunde følge en eenstemmig Forestilling fra deres Hænder til Kongen. Var man gaaet videre i Sagen, er det vel endda troligt, at der vilde være kommet til at foreligge en Flertalsindstilling til Kongen, der gik imod selve Præsidentens Standpunkt og ikke vilde stemme med Frederik VI.s Ønsker. Resultatet var derfor uundgaaeligt: Man indskrænkede sig til de nævnte Kundgørelser med Kravet om Embedskandidaters Duelighed i Dansk, og selve Sprogsagen blev — formodentlig med Kongens stiltiende Samtykke - „henlagt". Der skulde gaa 40 Aar, inden den atter blev taget op, og da under helt forandrede ydre Betingelser. 